\title{
Controls on Quaternary coastal evolution of the east-northeastern coast of Brazil: roles of sea-level history, trade winds and climate
}

\author{
José Maria Landim Dominguez a ${ }^{a}$ Abilio Carlos da Silva Pinto Bittencourt ${ }^{\text {a }}$ \\ and Louis Martin ${ }^{b}$ \\ ${ }^{a}$ Programa de Pesquisa e Pós-Graduação em Geofísica, UFBA, Rua Caetano Moura 123, Federação, 40210-Salvador, Bahia, Brazil \\ ${ }^{b}$ O.R.S.T.O.M., 70-74 Route D'Aulnay, 93140-Bondy, France
}

(Received December 15, 1991; revised version accepted June 30, 1992)

\begin{abstract}
Dominguez, J.M.L., Bittencourt, A.C.S.P. and Martin, L., 1992. Controls on Quaternary coastal evolution of the east-northeastern coast of Brazil: roles of sea-level history, trade winds and climate. In: J.F. Donoghue, R.A. Davis, C.H. Fletcher and J.R. Suter (Editors), Quaternary Coastal Evolution. Sediment. Geol., 80: 213-232.
\end{abstract}

East-northeastern Brazil has a wave-dominated, micro- to meso-tidal coast, lying entirely within the southern Atlantic trade wind belt. Integration of geologic mapping, radiocarbon dating and vibracoring data shows that the Quaternary coastal evolution of this area was controlled by three major factors: (1) sea-level history; (2) trade winds; and (3) climate change.

Sea-level history. Along the east-northeastern coast of Brazil, relative sea level has fallen approximately $5 \mathrm{~m}$ during the last $5000 \mathrm{y}$. Correlation of this sea-level history with the evolution of beach-ridge, lagoonal and coastal plain deposits shows that: (1) sea-level rise favours the formation of barrier island-lagoonal systems and the construction of intralagoonal deltas; (2) sea-level lowering is not conducive to barrier island formation. Rather, lagoons and bays become emergent and beach-ridge plains rapidly prograde.

Trade winds. Sediment dispersal systems along the coastal zone of east-northeastern Brazil have been highly persistent since Pleistocene time, as deduced from beach-ridge orientation. This persistence results from the fact that sediment dispersal in wave-dominated settings is ultimately controlled by atmospheric circulation which, for the east-northeastern coast of Brazil is associated with the South Atlantic high-pressure cell. The remarkable stability of this cell through time, has allowed the accumulation of extensive beach-ridge plains at the longshore drift sinks located along the coast.

Climate change. Effects of Quaternary climate changes on coastal sedimentation are twofold. Climate changes may affect rainfall patterns, thus exerting an important control on coastal dune development. Along the coast of northeastern Brazil, active coastal dunes are only present in those areas in which at least four consecutive dry months occur during the year. Mapping of these areas has shown that dune development during the Holocene has been episodic, these episodes being probably controlled by variations in rainfall patterns associated with climate changes. Secondly, despite its overall stability, the position of the high-pressure cell has experienced small shifts in position during the Holocene in response to climate changes. Changes in wind direction associated with these shifts have induced modifications in the coastal dispersion system, which are recorded in the strandplains as small truncations in the beach-ridge alignments.

These results have important implications in understanding accumulation of ancient sandstone shoreline sequences.

\section{Introduction}

What are the major controls on the development and preservation of coastal sequences in

Correspondence to: J.M.L. Dominguez, Programa de Pesquisa e Pós-Graduação em Geofísica, UFBA, Rua Caetano Moura 123, Federação, 40210-Salvador, Bahia, Brazil. terrigenous wave-dominated coasts? Most authors agree that changes in sea level, sediment supply and coastal processes are the dominant factors. However, changes in sea level are usually equated to sea-level rise. Coastal sequences are assumed to be deposited preferentially during a stable or slowly rising sea level. Falls in relative sea level are usually equated to non-deposition 
and widespread development of erosional surfaces. As a result barrier island-lagoonal systems are considered to be the dominant mode of sedimentation in both modern and ancient coastal settings. Also, the barrier island model has been extensively used to interpret the geologic record of coastal sequences.

Insufficient attention has been given to the role of climate in coastal processes, except as a factor controlling the overall distribution of climatically sensitive facies. Eolian activity, which is an important process acting along many of the world's shorelines, has aroused only a marginal interest from coastal scientists. This lack of interest is maybe the major reason for the relative paucity of literature dealing with this subject.

Possible reasons for the deficiencies observed above are: (1) Most of the global literature is produced in the Northern Hemisphere, where barrier island-lagoonal systems are the dominant coastal type. Also, because these shorelines are transgressive and experience erosional retreat, important coastal dune fields are not a frequent feature along the coastal zone. (2) There are few published details of terrigenous littoral zone deposits formed during falling relative sea level. The sole examples in the literature are recent terraces and beach ridges in isostatically rebounding regions, which are characterized by limited or absent sediment supply, and high rates of sea-level fall (20 m per $1000 \mathrm{y}$ ) (Heward, 1981).

East-northeastern Brazil has a wave-dominated, micro- to meso-tidal, falling sea-level coast, lying entirely within the southern Atlantic trade wind belt (Fig. 1). These factors have exerted a fundamental control on Quaternary coastal sedimentation in the area. The purpose of this paper is to present an overview of the large-scale controls of the Quaternary coastal evolution of eastnortheastern Brazil. Integration of geologic mapping, radiocarbon dating and vibracoring data shows that the Quaternary coastal evolution of this area was controlled by three major factors: (1) sea-level history, (2) trade winds, and (3) climate. Data used in this paper are from several papers published by the authors during the last fifteen years for the sector of Brazil's coastline that stretches from $20^{\circ}$ to $5^{\circ} \mathrm{S}$ lat. (Fig. 1).

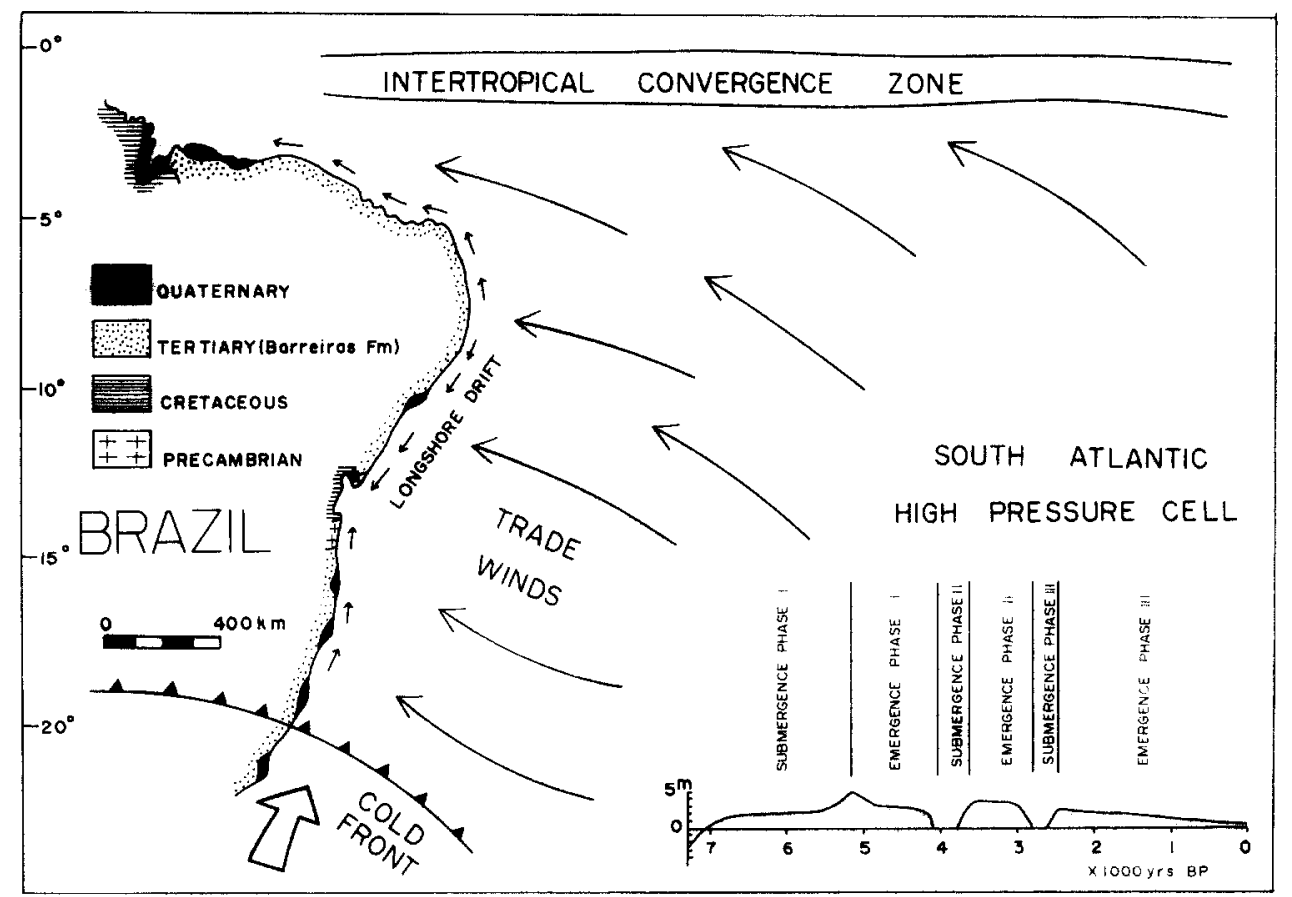

Fig. 1. Simplified geological map of the coastal zone of east-northeastern Brazil. Also depicted are the major elements of the atmospheric circulation affecting the coastal zone and the relative sea-level curve valid for the east coast. Sea-level curve after Martin et al. (1979). 


\section{Regional setting}

\section{Geology-geomorphology}

Three important physiographic units characterize the east-northeastern coast of Brazil (Fig. 1). (1) The Quaternary strandplains comprising Pleistocene and Holocene beach-ridge terraces, Holocene fluvial terraces, lagoonal, freshwater swamp, mangrove swamp and eolian deposits. The shoreline is more or less continuous, interrupted only by river mouths. Barrier islandlagoonal systems and estuaries are virtually absent from the shoreline. (2) The Tertiary Barreiras Formation, comprising unconsolidated, coalescing alluvial fans that form an almost flat, seaward-dipping surface, $10-40 \mathrm{~km}$ wide and 10 $100 \mathrm{~m}$ in elevation. The Barreiras Formation occurs almost continuously along the entire coastal zone. A line of fossil sea cliffs marks the boundary between these deposits and the Quaternary strandplains. In some places the Barreiras Formation reaches the coastline forming active cliffs. (3) The hinterland is characterized by rounded hills sculpted into the Precambrian shield with altitudes varying from 200 to $1000 \mathrm{~m}$. Minor portions of the hinterland are characterized by sedimentary rocks of Phanerozoic age.

\section{Sea-level changes}

During the last fifteen years relative sea-level curves were constructed for different sectors of the east-northeastern coast of Brazil (Martin et al., 1979; Suguio et al., 1979; Martin et al., 1985a). Sea-level indicators used in constructing the curves included: (1) vermetid gastropod incrustations, (2) beach-ridge terraces, (3) sandstone reefs (cemented upper shoreface deposits), (4) beachrocks (cemented foreshore deposits), (5) coral, (6) calcareous algae, (7) shell middens, and (8) lagoonal sediments. Despite minor discrepancies these curves show an important sea-level highstand around $5.1 \mathrm{ka}$ followed by a generally falling relative sea level since that time (Fig. 1). This fall was not regular, but interrupted by high-frequency sea-level oscillations. In each of these oscillations, sea level first fell to slightly below the present level, followed later by a sharp rise to approximately its former position (Fig. 1).

\section{Atmospheric circulation}

The basic elements of the general atmospheric circulation pattern along the east-northeastern coast of Brazil include (Bigarella, 1972) (Fig. 1): (1) air masses originating in the South Atlantic high-pressure cell; and (2) periodic advances of air masses of polar origin. Hurricanes do not form in the South Atlantic Ocean, thus, this type of atmospheric disturbance does not affect coastal processes in Brazil.

The South Atlantic anticyclone cell constitutes the main centre of circulation. This anticyclone cell is located at a fairly fixed position on the South Atlantic Ocean, and undergoes only slight seasonal variations. This permanence is reflected in the extreme constancy in speed and direction of the trade winds.

In the eastern and northern parts of the South Atlantic, the anticyclone cell causes trade winds to blow towards the equator (Fig. 2). These winds constitute the southeasterly and easterly winds on the north-northeastern coast of Brazil (Fig. 2). In the southwestern part of the high-pressure cell the "return" trade winds blow over the eastern Brazilian coast as northeasterly or easterly winds (Figs. 2A and 2D). The zone where the trade winds and the "return" trade winds diverge is called the zone of divergence. Along the coast this zone moves equatorwards during the summer (Figs. 2A and 2D) and southwards during the winter (Figs. $2 \mathrm{~B}$ and $2 \mathrm{C}$ ). This divergence zone is located around $13^{\circ} \mathrm{S}$ during January and $20^{\circ} \mathrm{S}$ during July (Figs. 2A and 2C). This zone of divergence corresponds to the limit between two air masses, the Equatorial Atlantic and the Tropical Atlantic (Nimer, 1989). As a result, during the summer, northeasterly and easterly trade winds blow along the east coast of Brazil. During the winter southeasterly winds dominate. North of the zone of divergence no significant seasonal change in wind direction occurs (Fig. 2).

The seasonal migration of the divergence zone is related to two phenomena: (1) the seasonal latitudinal shift of the South Atlantic high-pres- 


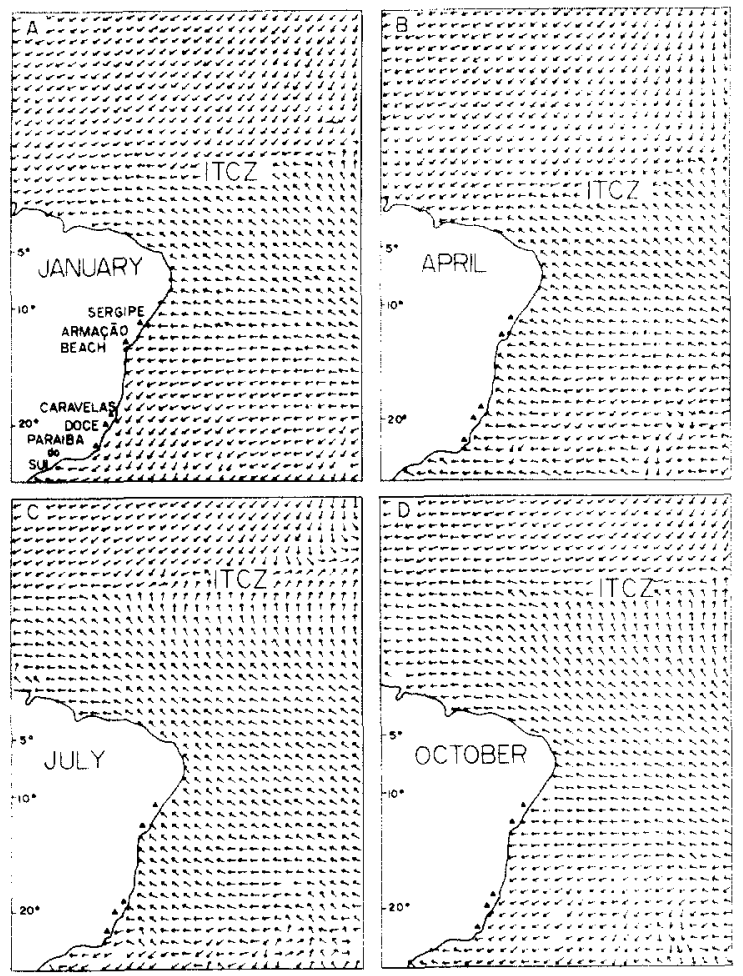

Fig. 2. Resultant winds for part of the Atlantic Ocean, for the months of January, April, July and October (modified from Hastenrath and Lamb, 1977). Note the convergence of the trade winds along the Intertropical Convergence Zone (ITCZ).

sure cell of the order of $5^{\circ}$, responding to changes in insolation related to the seasons of the year; and (2) during the summer, heating of the South American continent creates a thermal depression that forces the trade winds to tangent the east coast of Brazil.

Antarctic polar fronts invade the South American continent as great anti-cyclones east of the Andes Mountain range. These fronts, conditioned by the thermal contrast between land and sea and by the physiography of the continent, split into two branches. The eastern branch moves along the coast towards the equator reaching latitudes as far north as $10^{\circ} \mathrm{S}$ during the winter. The cold fronts rarely reach latitudes lower than $15^{\circ} \mathrm{S}$ during the summer.

South-southeast winds associated with the advance of these polar air masses reinforce the southeasterly winds generated at the anticyclone high-pressure cell. Gale-force winds $(25 \mathrm{~m} / \mathrm{s})$ have been reported associated with these polar air masses advancing along the coast (Bandeira et al., 1975).

\section{Wave climate}

No direct, long-term wave measurements are available for the east-northeastern coast of Brazil. Thus, the wave climate affecting this sector of the Brazilian coastline was deduced from published wave statistics (Hogben and Lumb, 1967; U.S. Navy, 1978) and from knowledge of the mechanisms responsible for wave generation in the South Atlantic Ocean.

Davies (1972) has identified two favourable regions in the South Atlantic Ocean where wave generation can take place: (1) the temperate high mid-latitude storm belt, and (2) the trade wind belt.

The temperate storm belt $\left(47^{\circ}-56^{\circ} \mathrm{S}\right)$ is the most important and clearly definable wave-generating area in the South Atlantic (Davies, 1972). This is a stable region characterized by a highfrequency of occurrence of gale-force winds (mean velocities in excess of about $17 \mathrm{~m} / \mathrm{s}$ ). The swell emanating from this area, however, probably does not exert any significant influence on coastal processes along the east-northeastern coast of Brazil because the westerly component of the temperate latitude gales is much more important than the easterly component. Since the direction which the waves take is controlled by the direction of the generating wind, a southwesterly swell dominates in the South Atlantic Ocean (Davies, 1972).

The trade wind belt located $10^{\circ}-20^{\circ} \mathrm{S}$ from the equator is characterized by a high frequency of winds of force 4 and over (minimum speed of 5 $\mathrm{m} / \mathrm{s}$ ). Force-4 velocities are a minimum below which waves of normal geomorphic significance are unlikely to be generated (Davies, 1972). Because of the extreme constancy in the speed and direction of the trade winds, and the geographic location of the east coast of Brazil lying entirely within the trade wind belt, waves generated by these winds strongly influence coastal processes in this section of the Brazilian coast. As observed by Davies (1972) the only extensive stretches of 
continental coast strongly influenced by waves generated by tropical easterlies lie in Brazil and East Africa. The available wave statistics (Hogben and Lumb, 1967; U.S. Navy, 1978) corroborate the assumptions made above. These statistics show the direct relationship between the direction and speed of the trade winds and the direction, height, and period of waves impinging on the east-northeastern coast of Brazil. For the east coast, although N-NE waves are somewhat present all year around, beginning in April and extending through August, E-SE waves comprise a significant percentage of the wave trains impinging on the coast. The E-SE wave trains are associated with the easterly and the southeasterly trade winds that blow on the east coast of Brazil during the same period. Thus, during the fall (Apr.-May) and the winter (Jun.-Aug.) eastsoutheastern waves with average heights of $1.5 \mathrm{~m}$ and average periods of 6 to $7 \mathrm{~s}$ are common. During the spring (Sep.-Nov.) and the summer (Dec.-Feb.) north-northeastern waves with average heights of $1.0 \mathrm{~m}$ and periods of $5 \mathrm{~s}$ or less dominate on the east coast of Brazil. For the northeastern coast of Brazil north of $10^{\circ} \mathrm{S}$, E-SE waves with average heights of 1 to $1.5 \mathrm{~m}$ and periods of 5 to $7 \mathrm{~s}$ dominate year around.

During the winter, wave generation along the east coast of Brazil is also influenced by the northward advance of the polar air masses. Associated southeasterly winds generate waves having that preferential direction of propagation. These air masses rarely move far enough to the north to play an important role in coastal processes in northeastern Brazil.

\section{Longshore transport}

No long-term measurements of wave-generated longshore currents are available for the study area. The preferential direction of longshore drift can be estimated from the direction of propagation of wave trains relative to initial shoreline orientation. These estimations can then be checked against geomorphic indicators (e.g., direction of migration of sand spits). For the purpose of this discussion the study area can be divided into two sectors: (1) from $20^{\circ}$ to $13^{\circ} \mathrm{S}$, and (2) from $13^{\circ}$ to $5^{\circ} \mathrm{S}$.

\section{Sector I}

It is clear from the previous section that two wave trains, primarily generated by trade winds, impinge on this sector of the coastline: (1) northnortheastern waves about $1.0 \mathrm{~m}$ high and with periods of less than $5 \mathrm{~s}$; and (2) east-southeastern waves about $1.5-2.0 \mathrm{~m}$ high and periods of 6 to 7 s. These are reinforced during the winter by vigorous south-southeastern waves associated with the advance of polar fronts. Although these storm waves are effective only during relatively small periods of time, longshore transport rates associated with them are much higher than those associated with the waves generated by the trade winds. Also, since wave energy varies with the square of the wave height, east-southeastern waves associated both with the trade winds and the advance of the polar air masses will be much more important in determining the configuration of the shoreline than north-northeastern waves in sector I. Thus, a preferential northward-directed longshore drift is predicted for sector I, since for this sector the initial shoreline orientation has an overall N-S trend (Fig. 1).

\section{Sector II}

East-southeastern waves associated with the trade winds dominate year-round. The overall longshore drift direction is determined by the interaction between the wave trains and the initial orientation of the shoreline (Fig. 1).

The initial orientation of the shoreline is considered here to be the line of fossil sea cliffs carved into the Late Tertiary Barreiras Formation sometime during the Pleistocene. This line can assume various orientations as shown in Fig. 1. Assuming this initial shoreline and the dominance of the wave trains discussed above, preferential longshore drift directions are plotted in Fig. 1. Geomorphic indicators along the eastnortheastern coast of Brazil, as observed on various published maps and aerial photographs corroborate these conclusions (Martin et al., 1980; Bittencourt et al., 1983a; Dominguez et al., 1983, 1990; Barbosa et al., 1986a, b). 
Climate along the coastal zone varies from hot super-humid to hot semi-arid. Annual rainfall along the coast usually exceeds $125 \mathrm{~cm}$, with maxima around $200 \mathrm{~cm}$. Mean annual temperature along the coast varies from $24^{\circ}$ to $26^{\circ} \mathrm{C}$ (Nimer, 1989).

Figure 3 depicts the duration of the dry periods along the east-northeastern coast of Brazil (Nimer, 1989). This figure shows that the northeastern region presents significantly longer periods without precipitation than the eastern region. The number of consecutive dry months gradually increases northwards of the São Francisco River mouth. Around $5^{\circ} \mathrm{S}$, six to eight dry consecutive months occur during the year.

\section{Controls on Quaternary coastal evolution}

Sea-level history

Integration of the regional sea-level history with detailed mapping and radiocarbon dating of the beach-ridge strandplains along the east coast of Brazil has shown that sea-level history has exerted a fundamental control on the styles of sedimentation in coastal regions. An evolutionary scheme proposed for these beach-ridge plains is presented in Fig. 4. Since details of this evolutionary history are published elsewhere (Dominguez, 1987; Dominguez et al., 1987; Dominguez and Wanless, 1991; Martin and Dominguez, 1992) they will not be repeated here.

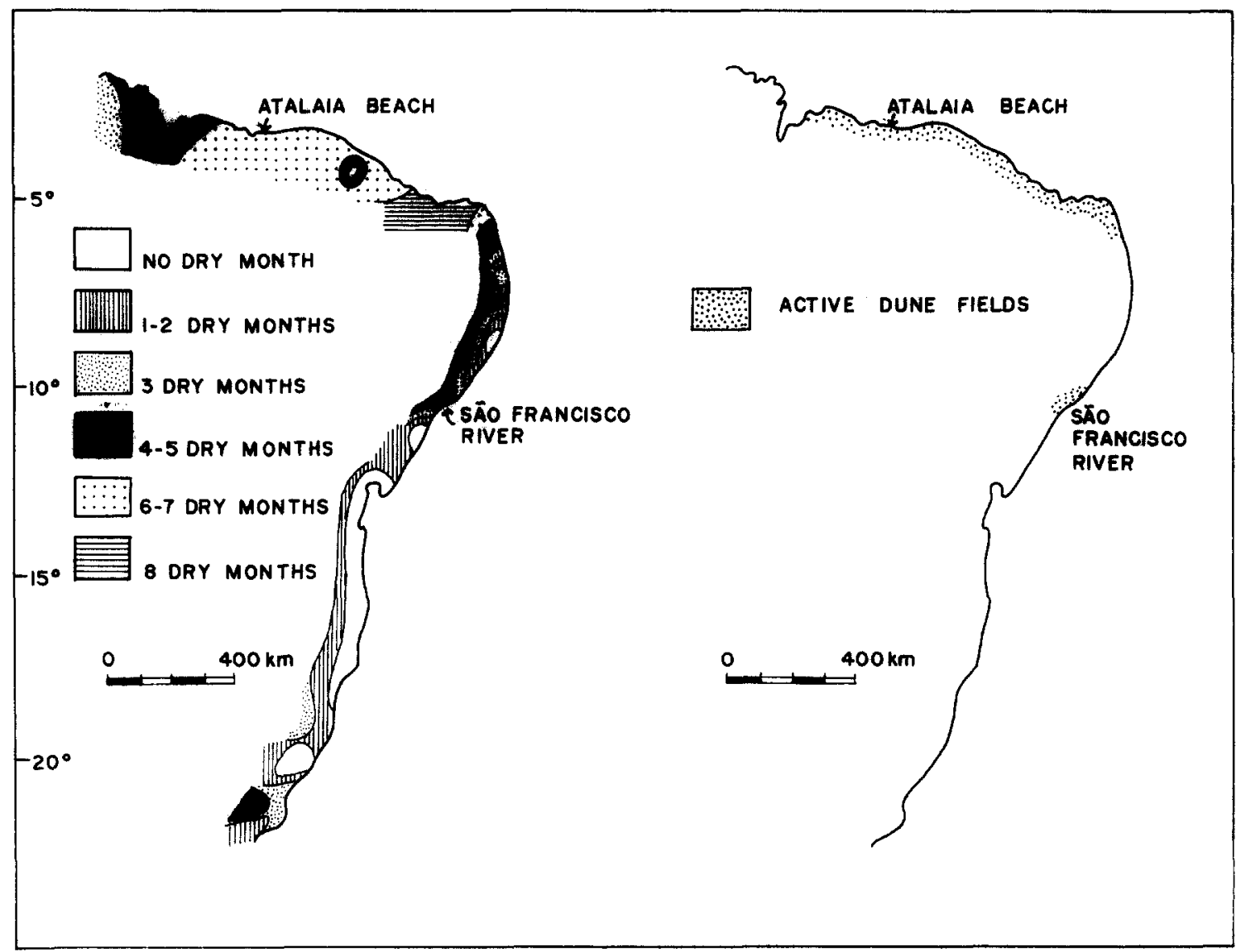

Fig. 3. Distribution of the number of consecutive dry months along the east-northeastern coast of Brazil, together with the occurrence of active dune fields. 
(A)

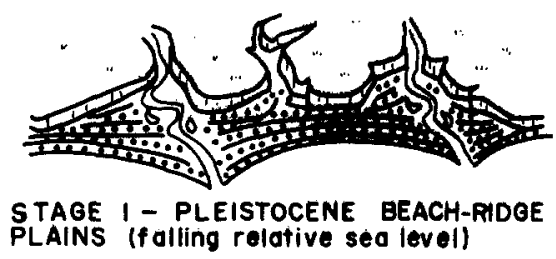

(c)

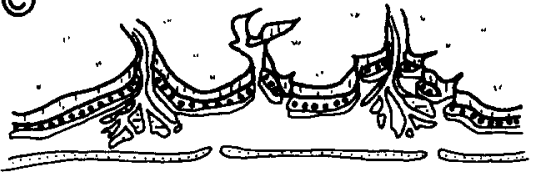

STAGE III - INTRALAGOONAL DELTAS

$$
\begin{aligned}
& \frac{z}{2} \frac{z}{x} \text { WETLANDS } \\
& \text { 二- = FLUVIAL }
\end{aligned}
$$

(B)

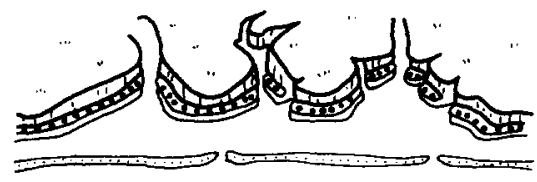

STAGE $\|-M A X I M U M$ HOLOCENE

TRANSGRESSION $5.1 \mathrm{kO}$

BARRIER ISLAND / LAGOON

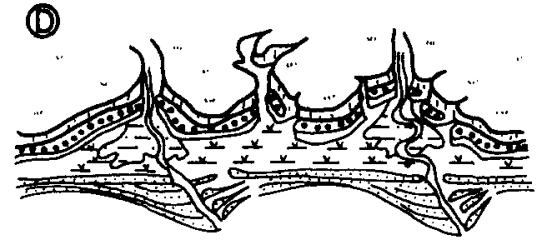

STAGE IV-HOLOCENE BEACH RIDGE PLAINS (falling relative sea level)

HOLOCENE BEACH RIDGES

\section{: PLEISTOCENE BEACH RIDGES}

Fig. 4. Simplified evolutionary scheme for the east-northeast coast of Brazil showing the role exerted by sea-level history on coastal development (modified from Dominguez et al., 1987).

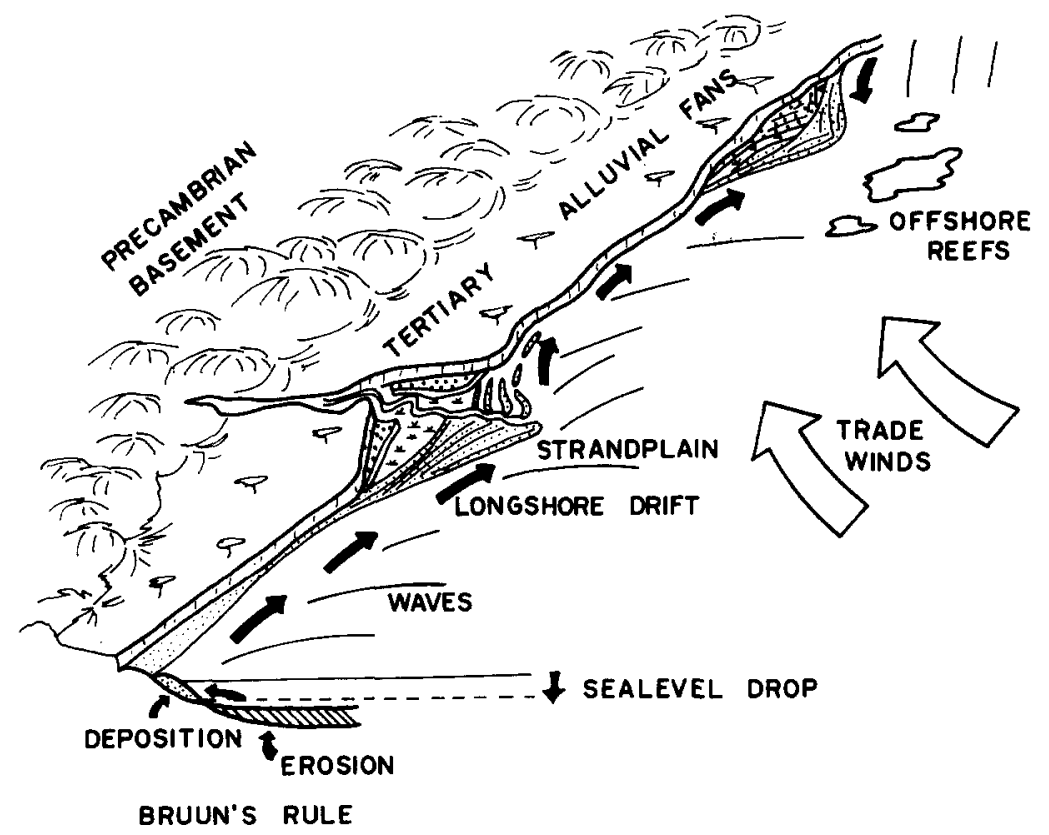

Fig. 5. Conceptual model for sediment dispersion and accumulation along the east-northeastern coast of Brazil. As relative sea-level falls, sediments eroded from the lower part of the beach profile following the inverse of Bruun's rule, are transferred to the upper part of the profile, where, together with sediments from other sources (e.g. riverborne, erosion of sea cliffs, etc.) they are redistributed along the coast by longshore drift. The sediments are stored in areas protected by offshore reefs, embayments, and river mouths. Sediment dispersal is intimately related to waves generated by the trade winds. 
As pointed out by Dominguez (1984) and Dominguez et al. (1987) existing coastal sedimentation models have not properly incorporated the fundamental role of Holocene sea-level history on coastal evolution. For example, the classic work by Coleman and Wright (1975), although analyzing the influence of as many as 400 different parameters on the geometry of deltaic sand bodies, did not address the effects of Holocene sea-level oscillations. Coastal sedimentation models focus on tidal range, wave energy, and fluvial discharge as the primary controls on the general framework of coastal sedimentary environments (Fisher, 1969; Galloway, 1975; Hayes, 1979). The strong emphasis placed on factors such as wave energy, tidal range, and river discharge is probably the result of the general belief, which persisted until very recently, that modern sea level has been rising or at least has been stable everywhere during the last $4000 \mathrm{y}$.

Work done along the east-northeastern coast of Brazil (Bittencourt et al., 1981; Dominguez et al., 1981, 1987; Suguio et al., 1981; Martin et al., 1984a; Barbosa et al., 1986a; Dominguez and Wanless, 1991; Martin and Dominguez, 1992) has demonstrated that, during rising sea level, barrier island-lagoonal systems are the dominant mode of sedimentation. Rivers do not reach directly the continental shelf but tend to construct bayhead deltas in protected environments such as lagoons, bays or estuaries (Figs. 4B and 4C). Beach-ridge plains are virtually absent. This is the morphology that characterizes the United States Atlantic and western Gulf coasts, where during the last 5000 years sea level has been rising. This also was the dominant mode of sedimentation along the eastnortheastern coast of Brazil at $5 \mathrm{ka}$, during the maximum of the Holocene transgression.

By contrast, sea-level fall poses highly unfavourable conditions to the genesis and maintenance of barrier island-lagoonal systems. Lagoons and bays become emergent. Beach-ridge plains rapidly prograde, creating regressive sand sheets (Fig. 4D). Rivers empty directly onto the inner shelf. This is the case for east-northeastern Brazil, where narrow elongated barrier islands separated from the mainland by a lagoon are virtually absent today, although abundant in the past. These features have been replaced by extensive beach-ridge plains.

Sea-level fall makes available, besides riverborne sediments, a new source of sediment for the progradation of the shoreline. This is the reworking of the inner shelf sands, following an inverse of Bruun's rule. These sands are incorporated into the wave-generated longshore drift systems and finally come to rest in sediment traps located along the coast, such as river mouths, offshore obstacles, coastal re-entrants etc. (Fig. 5). Along the Brazilian coast, in many areas sediments provided in this way were more important than the fluvial input (Dominguez et al., 1983; Martin et al., 1985b).

\section{Trade winds}

As mentioned before the only extensive stretches of continental coast strongly influenced by waves generated by tropical easterlies lie in Brazil and East Africa. Because of the remarkable stability of the South Atlantic high-pressure cell, the trade winds starting at this cell will also show a remarkable stability. As a result it is expected that sediment dispersal along the eastnortheastern coast of Brazil, which is ultimately controlled by atmospheric circulation will also be highly persistent. Integration of geologic mapping, radiocarbon dating and vibracoring data of the sedimentary deposits occurring in the Quaternary plains located on the east coast of Brazil, has allowed the construction of detailed evolutionary maps for these plains (Dominguez et al., 1981, 1987, 1990; Bittencourt et al., 1983b; Dominguez, 1983; Martin et al., 1984a; Barbosa et al., 1986a; Dominguez and Wanless, 1991). These palaeogeographic reconstructions show that sediment dispersal patterns along the eastnortheastern coast of Brazil have remained the same since Pleistocene time. Figure 6 shows simplified geologic maps of some important strandplains on the east coast of Brazil. In all these examples it is clear that the overall geometry of the Pleistocene beach-ridge deposits closely follows that of the Holocene beach-ridge deposits and the present-day shoreline. Although other areas around the world present evidence of this 


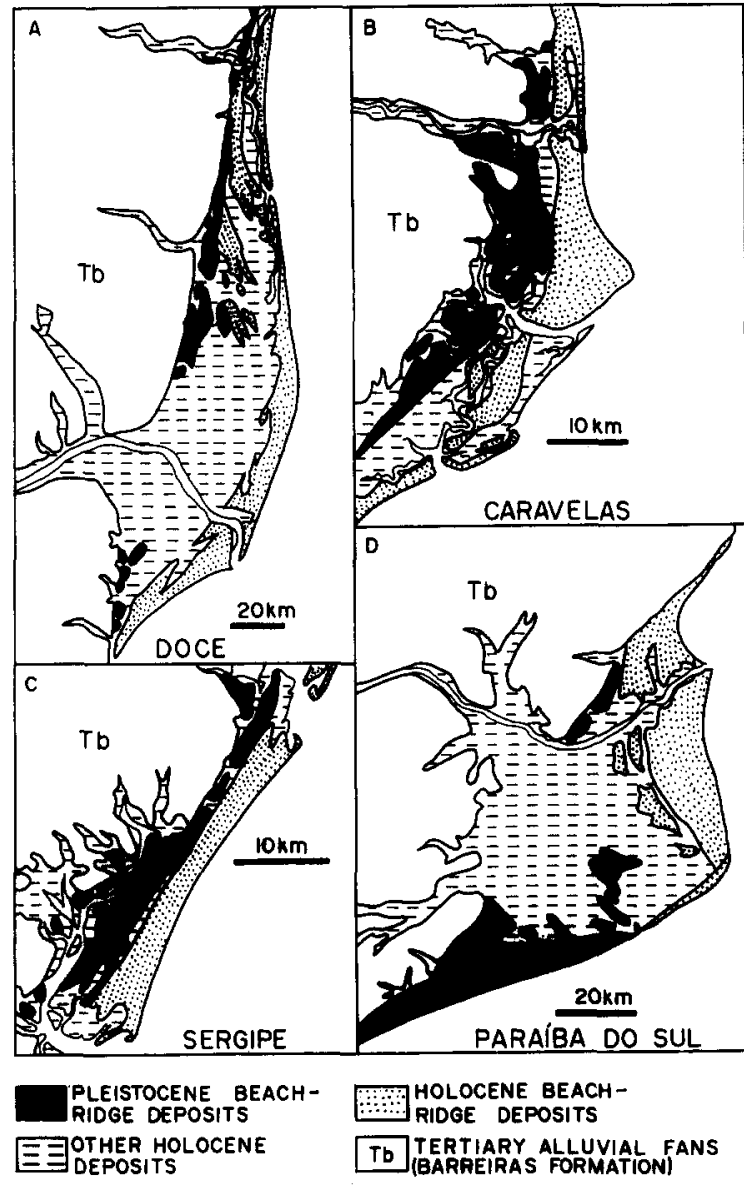

Fig. 6. Simplified geological maps of selected strandplains located along the eastern coast of Brazil illustrating the persistence of sediment dispersal and accumulation during the

Quaternary (see text for details and Fig. 2 for location).

persistence in dispersal systems (e.g. Cape Kennedy, NE Florida; Apalachicola River delta, NW Florida), this phenomenon is enhanced along the east-northeastern coast of Brazil because of its location with respect to the trade wind belt.

\section{Climate and its changes}

The effects of climate and its changes on coastal sedimentation along the east-northeastern coast of Brazil are twofold. Firstly, climate changes may affect rainfall patterns, thus exerting an important control on coastal dune development. Secondly, despite its overall stability, the position of the South Atlantic high-pressure cell can experience small shifts in position in response to climate change which, associated with changes in heating of the South American continent and other phenomena such as "El Niño", can cause changes in wind direction, thus inducing modifications in the coastal sediment dispersion systems. These two effects are discussed separately below.

\section{Dune development}

Some specialists (e.g. Goldsmith, 1978) have the opinion that climate is not a criterion for accumulation of eolian deposits along the coast, except along humid tropical areas. This belief is based on the assumption that cooling and warming between land and sea assures an onshore wind at least some of the time, regardless of the general wind circulation pattern. Although it is true that coastal dunes occur in virtually every climatic zone, probably within each of these zones coastal dune occurrence is controlled by the pattern of monthly rainfall distribution. Along the east-northeastern coast of Brazil, active migrating coastal dunes are only present in those sectors in which at least four consecutive dry months occur during the year (Fig. 3). These sectors are the Quaternary coastal plain associated with the São Francisco River mouth, and the north-northeastern coastline (Fig. 3). Mapping of some of these areas has additionally shown that, during the Quaternary, dune development has been episodic suggesting that climate has changed (Bittencourt et al., 1981). In addition, persistent onshore trade winds also constitute an important secondary factor favouring dune development along the eastnortheastern coast of Brazil.

Climate, through rainfall, controls not only the migration of active dunes but sediment supply to the dune field as well. A small field experiment conducted at the Atalaia beach (Fig. 3), located in northeastern Brazil has illustrated how this mechanism operates (Bittencourt et al., 1990). The Atalaia beach is associated with an extensive dune field characterized by isolated barchan dunes migrating in a southwest direction. The Atalaia beach is of the dissipative type (Wright and Short, 1983) exhibiting an ample low-declivity beach face, and no berm. Climate in this region is hot and humid with an annual precipitation of $100-125 \mathrm{~cm}$ which is essentially controlled by the 
position of the Intertropical Convergence Zone (ITCZ) (Figs. 1 and 2). The rainy season occurs in summer-fall when the ITCZ moves southwards and gets closer to the coast (Figs. 2A and 2B). During winter-spring the ITCZ moves away from the coast and the rains stop (Figs. 2C and 2D).

Monitoring of textural beach changes at the Atalaia beach have shown a close relationship between atmospheric precipitation and texture of beach-face sands (Bittencourt et al., 1990). Monitoring extended for a 9-month period and samples were always collected on the upper $2 \mathrm{~cm}$ of the beach face, in the middle point between the high- and low-tide level. Additionally, samples were collected as close as possible to the time when the low tide was reached. Figure 7 shows that during the rainy season median values for beach-face sands averaged $0.150 \mathrm{~mm}$, whereas during the dry season, median values of $0.700 \mathrm{~mm}$ were typical for the sediments. Also, wind speeds during the dry season were significantly higher than during the rainy season. No significant changes in beach profile have been observed during the monitoring period (Bittencourt et al., 1990). These authors have interpreted these changes as resulting primarily from the selective removal of beach-face sediments by wind action. Thus, during the wet season (Jan.-Apr.) the al- most uninterrupted rains stabilized the beach face (Fig. 7). This, in association with milder onshore winds, inhibited the removal of the fine sediment fraction from the beach face (Fig. 7). Accordingly, during this period beach sediments were made up mostly of fine to very fine sand with mean values averaging $0.150 \mathrm{~mm}$. On the other hand, during the dry season (Aug.-Dec.) onshore winds removed a significant portion of the fine to very fine sand size fraction of the beach-face sediments, probably depositing it on the adjacent active dune fields. Thus, higher median values $(0.700 \mathrm{~mm})$ characterized the beach-face sediments during this period.

Dune migration virtually stops during the rainy season and interdune areas are flooded, creating small ponds that become interconnected and drain to the sea (Figs. 8A and 8B). Migration resumes during the dry season, and interdune areas dry out (Fig. $8 \mathrm{C}$ ). As a result, interdune areas are characterized by the presence of low arcuate ridges, concave in the direction of dune migration (Fig. 8D). These arcuate ridges can be easily seen in aerial photographs and represent periods of interruption of dune migration. Similar features have been reported by Inman et al. (1966) and Purvis (1991) for interdune areas, respectively, in Mexico and southern Tunisia.

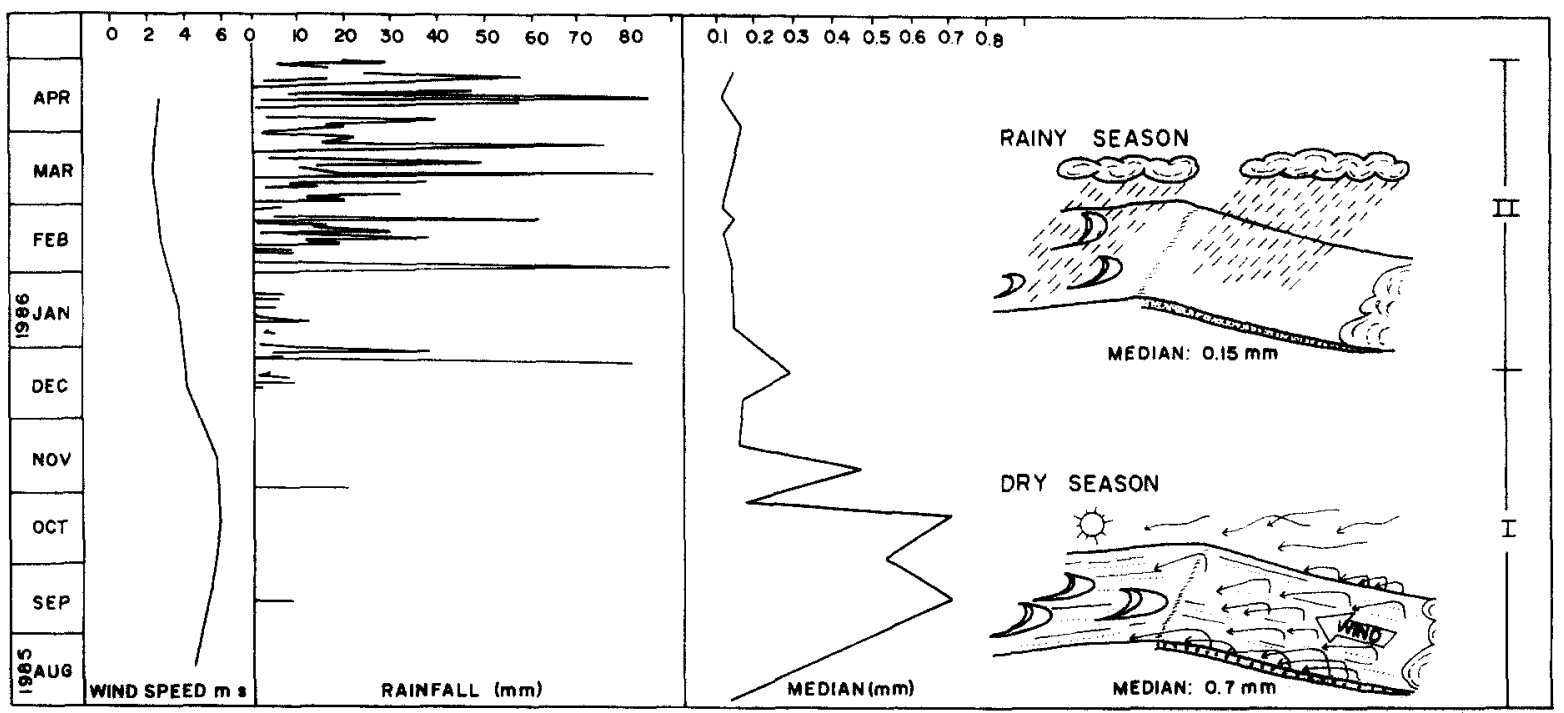

Fig. 7. Observed relationships between rainfall and median of beach-face sands at the Atalaia beach. Also depicted are wind speeds and a conceptual model illustrating the control that rainfall exerts on the selective removal by the wind of the fine-grained beach-face sands (see text for details) (modified from Bittencourt et al., 1990). 


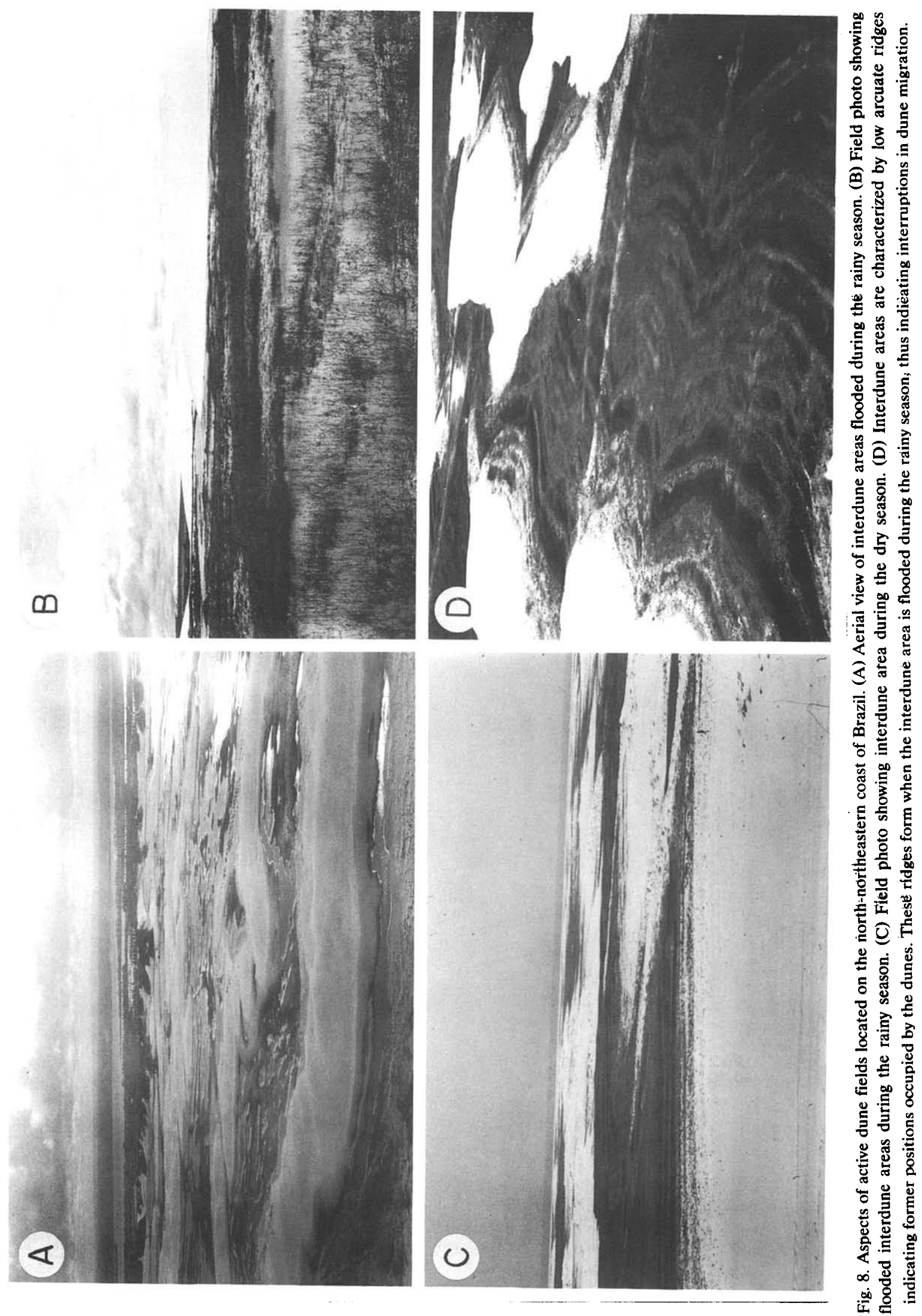


Since the source of sediment for the dune field is the beach face, any phenomena affecting the removal of sediments from the beach face will also affect the development of the dune field. It has been shown that for this area, sediment supply to the dune field and dune migration is confined to the dry season. Thus, for the Atalaia beach and associated dune field, any climatic change that impedes the southward movement of the ITCZ during summer-fall will result in a decrease in precipitation, increasing sediment supply to the dune field and favouring dune migration. Conversely, if the ITCZ does not move northwards during winter-spring, duration of the rainy season will increase and sediment supply to the dune field and dune migration will stop.

Aerial photographs of the Atalaia coastal plain suggest that sediment supply to the dune field during recent time was episodic (Fig. 9A). Assuming that longshore transport rates and grain size have remained constant during this period, the best candidate to explain this intermittent supply is a change in atmospheric precipitation related to the position of the ITCZ, acting on time scales of several decades.

For the São Francisco coastal plain (Fig. 3) any climate changes that result in a decrease in the length of the dry season will have similar effects. Mapping of the São Francisco coastal plain (Figs. $9 \mathrm{~B}$ and 10 ) has shown the existence of an inactive dune field of Holocene age located landward of and being transgressed by active dunes. This inactive dune field possibly records a climatic change affecting this area during the Holocene.

\section{Beach-ridge development}

Falling relative sea level over the last 5000 years has produced extensive beach-ridge plains on the east-northeastern coast of Brazil. Each beach ridge was formed individually as a deposit associated with an active shoreline. Thus, beach ridges represent a sort of "growth-rings" of the strandplain, and allow researchers to decipher the development history of the shoreline. Careful mapping of major beach-ridge plains along the east-northeastern coast of Brazil (Martin et al., 1980, 1984a; Dominguez, 1983, 1987; Dominguez and Wanless, 1991) has shown many different beach-ridge sets separated from each other by truncation lines, representing periods of shoreline erosion. These erosional episodes may have resulted from: (1) small rises in relative sea level such as those depicted on the sea-level curve (Dominguez, 1983, 1987); (2) changes in position
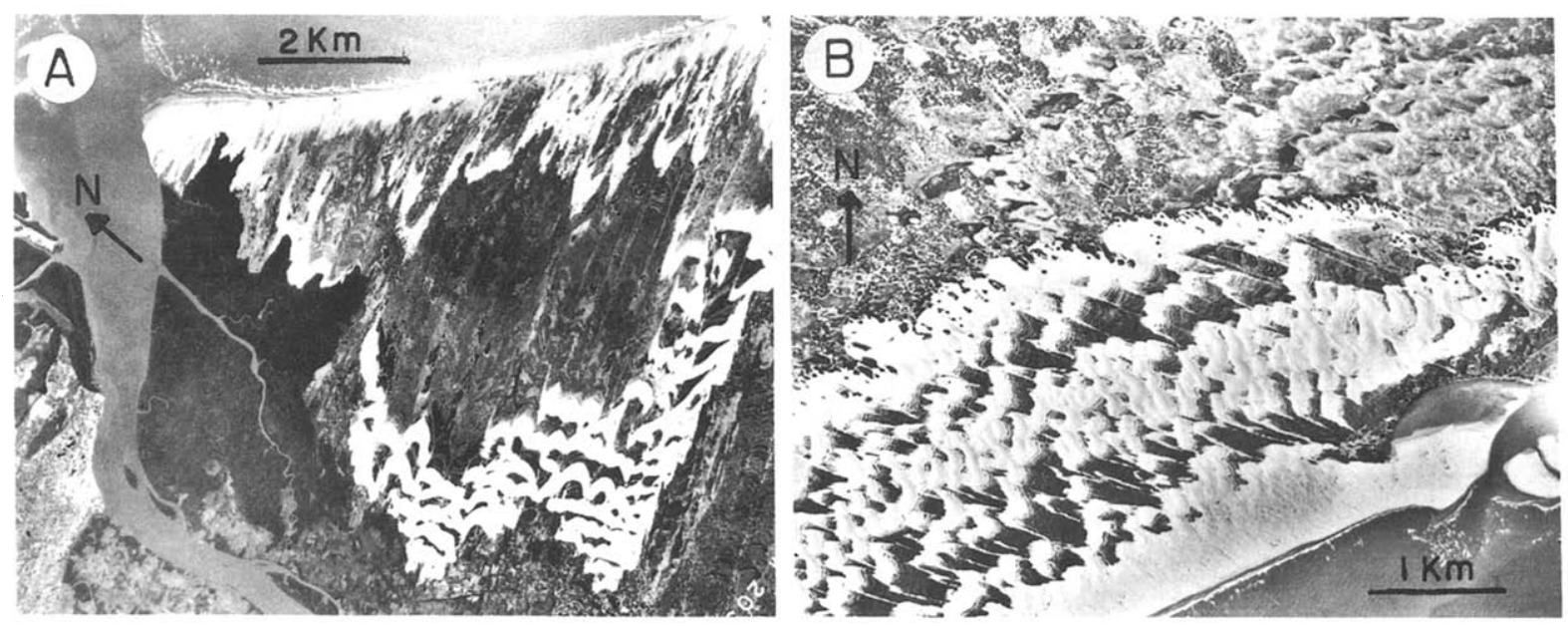

Fig. 9. Vertical aerial photos of active dune fields along the north-northeastern coast of Brazil. (A) Dune field occurring in the vicinity of the Atalaia beach illustrating discontinuous sediment supply. This intermittent supply may be related to short-term changes in rainfall possibly associated with the behaviour of the ITCZ. (B) Photo illustrating continuous sediment supply to the dune field located at the São Francisco strandplain. Note that there is no gap between the beach and the dune field itself. Interior area is an old dune field of Holocene age already stabilized by vegetation and thus illustrating the episodic character of dune development in the São Francisco strandplain, possibly related to recent climate changes. 
of the river mouths (Dominguez et al., 1983, 1987; Martin et al., 1984a; Dominguez and Wanless, 1991); and (3) inversions in the longshore drift direction associated with changes in wave climate (Martin et al., 1984b; Dominguez and Wanless, 1991), which for the east coast of Brazil would probably be the result of climatic changes.

Longshore dispersion of sediments can be climatically sensitive. Monitoring of beach profiles at the Armação beach (Fig. 1), during a 19-month period has shown a close relationship between the wind patterns and the wave-generated longshore drift direction (Farias et al., 1985) (Fig. 11). The Armação beach is a 3-km-long stretch of shoreline located between two rocky headlands that block any exchange of sediment between this beach and adjacent areas. Monitoring of beach profiles shows that the two ends of the beach exhibit opposite behaviours during the year. An erosional phase at one end corresponds to a depositional phase at the other. These beach cycles are not the same as those described by

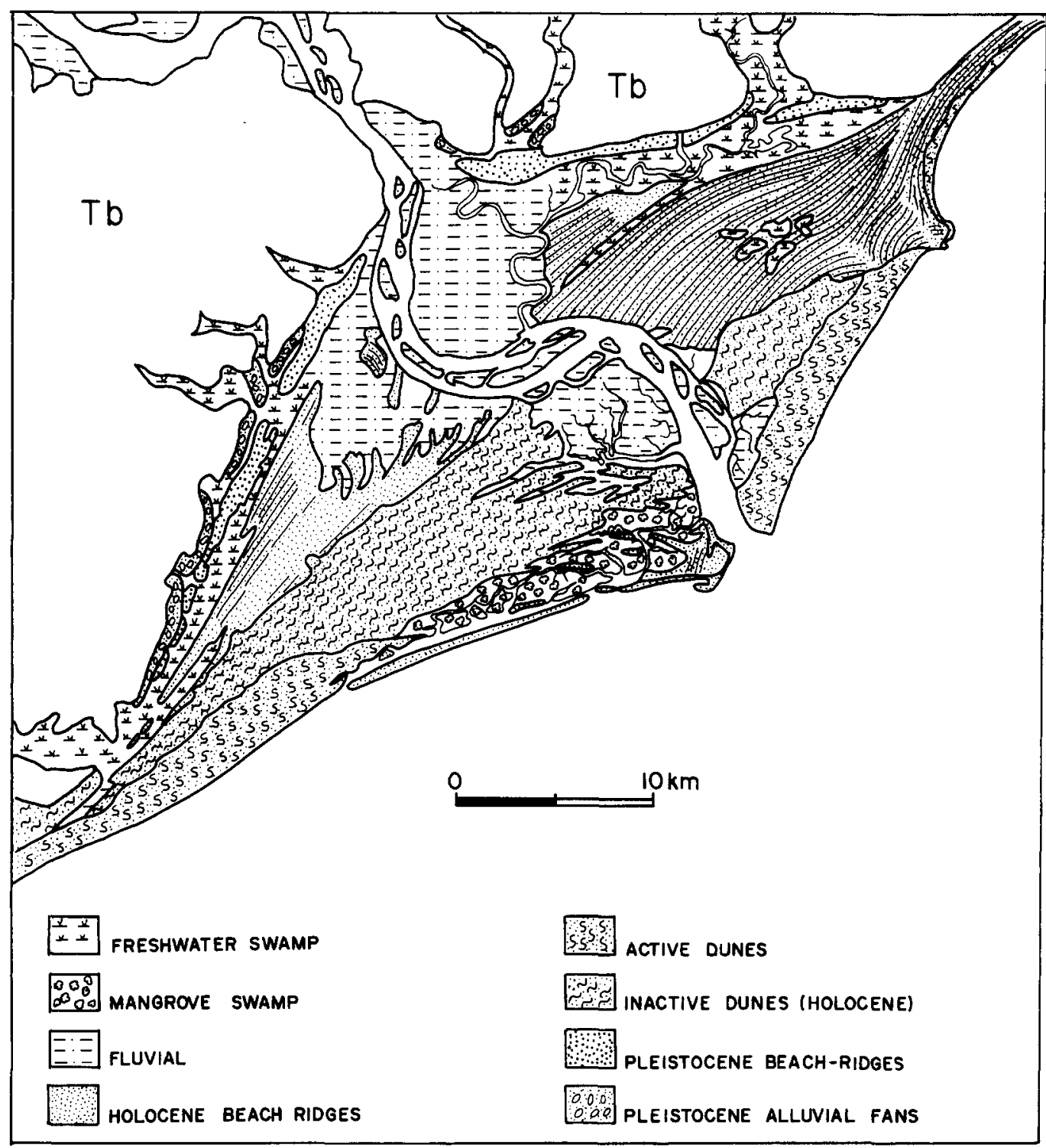

Fig. 10. Geomorphic map of the Quaternary deposits occurring at the São Francisco strandplain, showing the existence of two generations of dune fields of Holocene age. Stabilization of the older dune field is possibly related to climate change affecting this part of the coast. See Fig. 3 for location of the map. 


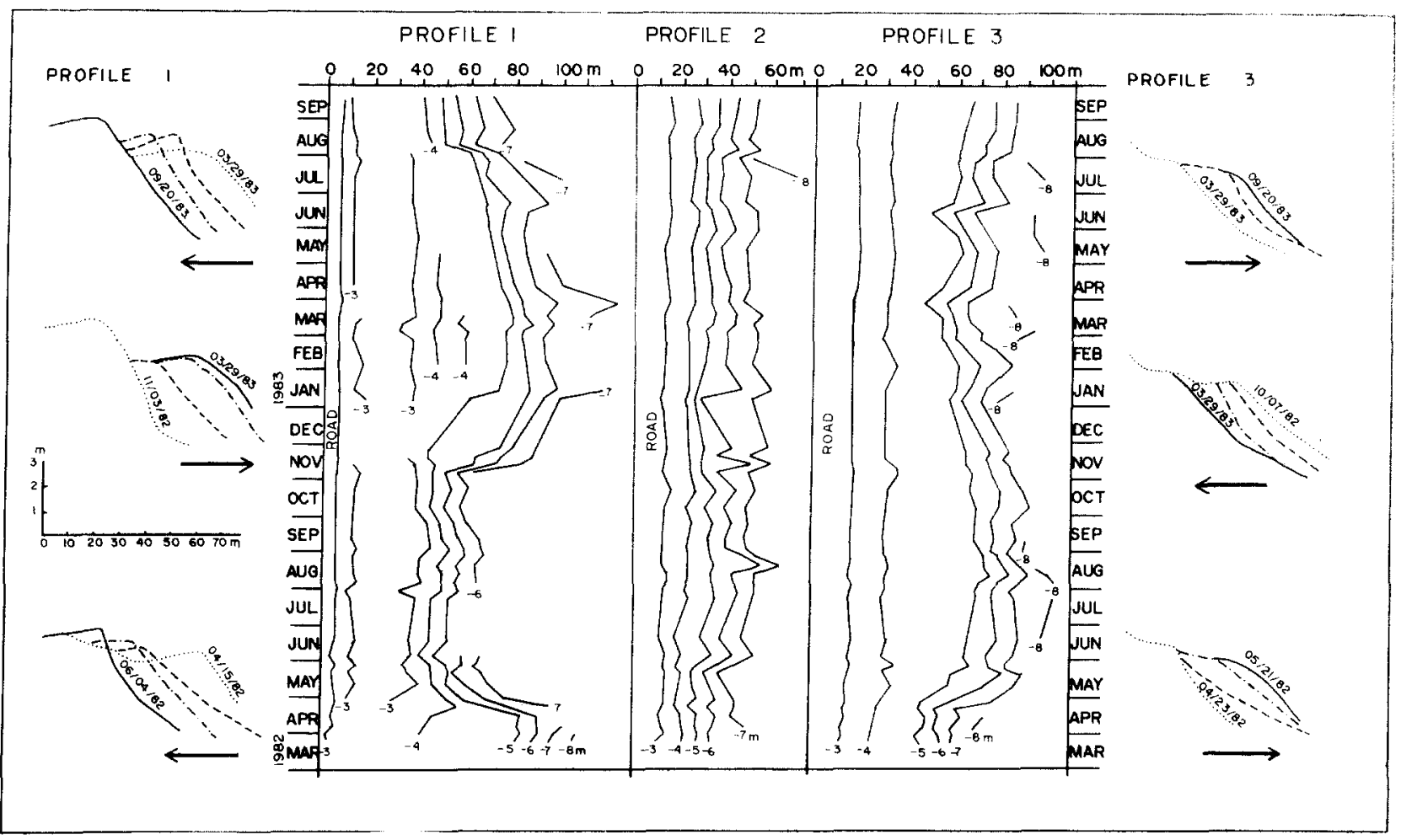

Fig. 11. Changes in beach profile through time documented for the Armação beach. Isopleth diagrams in the central part of the graph show variations in beach surface elevation through time measured from a horizontal datum that intercepts the beach prism in the backshore. Thus, differences in elevation are negative. Isopleths connect equal elevation points relative to this datum. Cross-sections of Profile 2 are not shown because almost no seasonal changes were observed at this location. Profiles 1 and 3 are, respectively, located at the southwestern and northeastern ends of the beach. See text for details (modified from Farias et al..

Shepard (1950) (i.e. winter-summer profiles), but result from seasonal changes in longshore drift direction related to changes in wind regime (Farias et al., 1985). These authors have shown that during those periods in which south-southeasterly winds dominated, the southern end of the beach (Profile 1, Fig. 11) experienced erosion, whereas a depositional phase characterized the northern end (Profile 3, Fig. 11). The opposite was true when the east-northeastern winds were dominant. No significant changes were observed in the intermediate profile (Profile 2, Fig. 11).

As discussed before, these seasonal changes in wave-wind regimes at the Armação beach, characterize the entire sector of the east coast of Brazil located between $13^{\circ}$ and $20^{\circ} \mathrm{S}$. They are related to the seasonal latitudinal shift of the South Atlantic high-pressure cell associated with changes in heating of the South American continent. Thus, any climate changes that affect one of these two factors will temporarily disrupt wind regimes along this sector of the coast, ultimately resulting in inversions in the longshore drift direction. If conditions are favourable (e.g. shoreline configuration, drift vs. swash-aligned beaches, etc.) these inversions can be permanently recorded on the prograding strandplains as changes in beach-ridge orientation.

Detailed mapping and palaeogeographic reconstruction of the Doce River strandplain (Dominguez, 1987; Dominguez and Wanless, 1991) (Figs. 2 and 12) have shown that between 5.1 and $3.8 \mathrm{ka}$, the northern part of this plain was affected by important inversions in the longshore drift direction, very possibly related to changes in wind regimes. Palaeogeographic reconstruction of 
the Doce strandplain shows that around $5.1 \mathrm{ka}$, a barrier island chain inflected abruptly landward, creating a broad embayment (Fig. 12A).

The tendency of the shoreface to maintain lateral continuity acts to prevent discontinuities of the shoreline (Swift, 1975). Therefore, when the shoreline curves landward into an embayment, such as at the northern part of the barrier island chain (Fig. 12A), coastal dynamics will work to seal it off. This sealing off took place according to the following mechanism. The shoreface, fed by the northward-directed long-

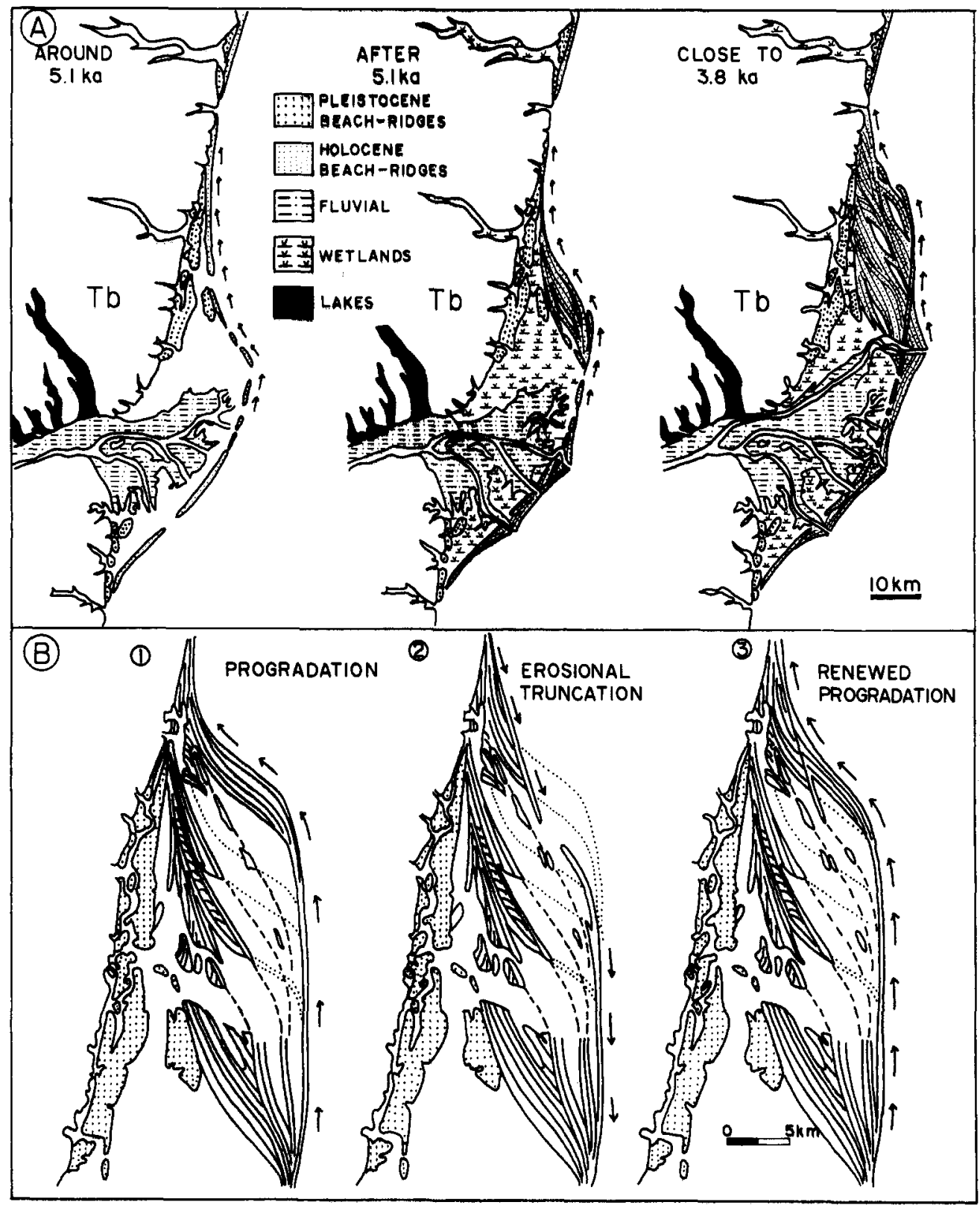

Fig. 12. Doce strandplain. (A) Palaeogeographic maps of the Doce strandplain from 5.1 to $3.8 \mathrm{ka}$ (modified from Dominguez, 1987). These maps correspond to stages III and IV of Fig. 4. (B) Enlargement of the northern part of the Doce strandplain illustrating the origin of truncations of the beach-ridge sets. These truncations result from inversions in the longshore drift direction. Dotted lines indicate orientation of the shoreline during periods of progradation. Dashed lines indicate orientation of the shoreline during periods of erosion associated with reversals in the longshore drift direction. Arrows denote direction of the longshore drift. 
shore drift, began prograding into this embayment. As a result of this lateral progradation, sand spits formed and extended northward into the open ocean, well away from the shoreline in the concave section. Refraction of the S-SE waves and waves impinging from the E-NE, drove the spit landward until its northern extremity welded to the shoreline in the concave side. In several cases this process gave rise to an extensive elongate lagoon separated from the open ocean by the spit itself. These lagoons later became the low-lying elongate areas separating the beachridge sets in the northern part of the strandplain. Temporary changes in atmospheric circulation caused inversions in the dominant direction of the longshore drift, from northward- to southward-directed. These inversions in the longshore drift were probably brief (tens of years), but were sufficient to cause truncation of the shoreline as observed in the northern part of the strandplain

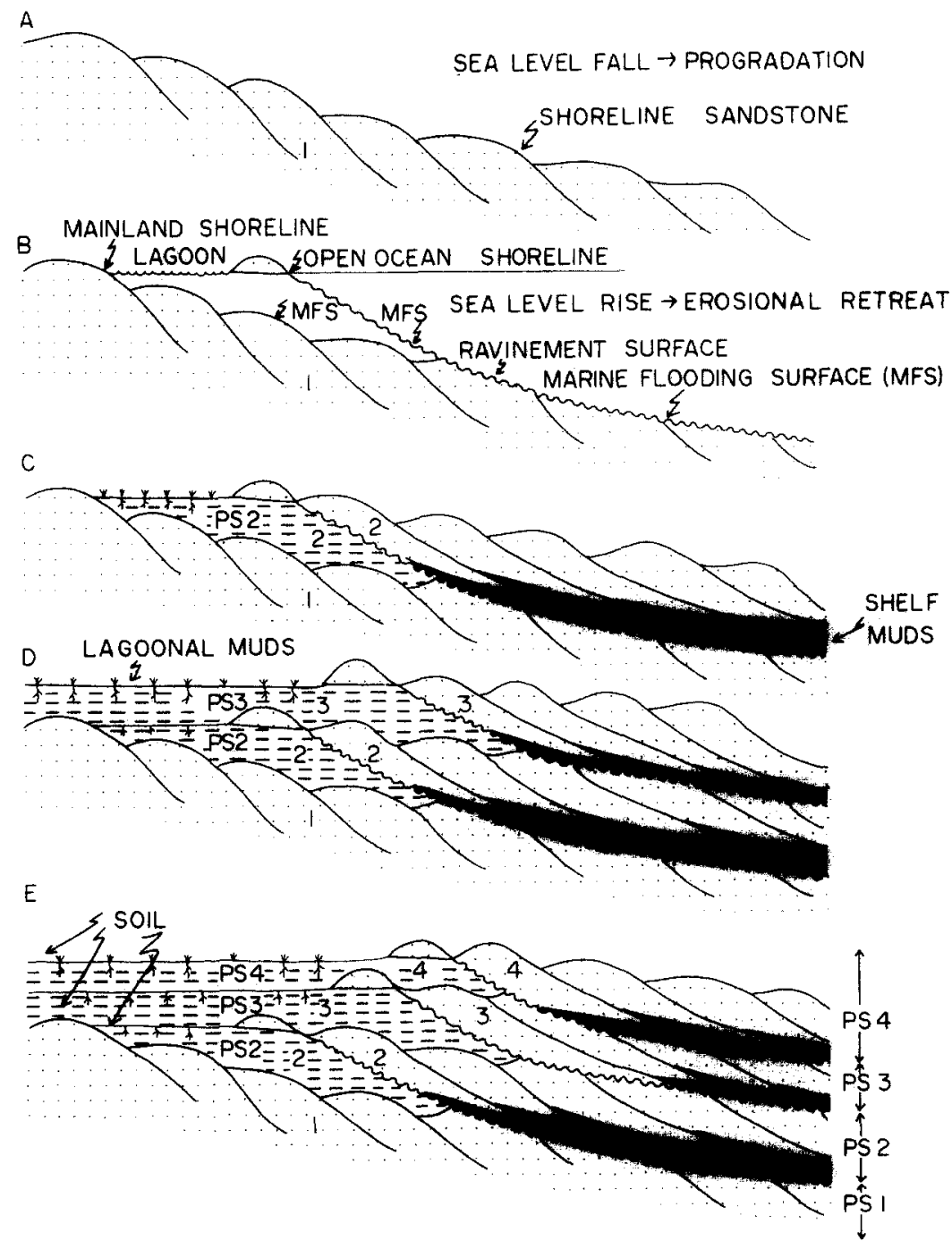

Fig. 13. Scheme showing formation of a progradational parasequence set. Each parasequence ( $P S$ ) results from progradation of the shoreline associated with a small drop in sea level, during an overall rise in relative sea level. Note that offshore, the marine flooding surface (MFS) coincides with the ravinement surface. Onshore, however, the MFS splits into two surfaces, across which there is an increase in water depth. These two surfaces bound the sedimentary prism deposited in the lagoon. Palaeo-soils will separate parasequences within the lagoonal sediments. See text for details. Numbers denote chronological order of deposition of sandstone shoreline parasequences and their correlatives in the lagoonal deposits. 
(Fig. 12B). Because these truncations are attributed to reversals in the longshore drift, they were called "shoreline reactivations" (Dominguez, 1987). The reversals in the longshore drift direction may be related to shifts in the position of the South Atlantic high-pressure cell and/or some other mechanism affecting the northward advance of the cold fronts.

Besides at the northern part of the Doce strandplain, reversals in the longshore drift direction have also been observed by us at the Caravelas strandplain (Figs. 2 and 6). However, because detailed palaeogeographic reconstructions are not available for this area, these reversals are not discussed here.

Truncations in beach-ridge alignment have also been reported for the Nayarit strandplain (Mexico) by Curray et al. (1967). These authors have also related these truncations to possible climatic changes.

\section{Conclusions}

This paper has discussed and presented an overview of the large-scale controls of the Quaternary coastal evolution of the east-northeastern coast of Brazil.

The results presented here provide important insights to the understanding of the accumulation of sandstone shoreline sequences. These sequences are very common in the geologic record reaching tens of metres in thickness and tens of kilometres in length.

Detailed work in regions where good outcrops of ancient littoral zone sequences are available, shows that these shoreline sandstones are composed of stacked parasequences (Ryer, 1977; Rice, 1980; Clifton, 1981; McCubbin, 1982; Balsley, 1983; Van Wagoner et al., 1990). These parasequences are similar in thickness and facies associations to those observed in the regressive sand sheets of east-northeastern Brazil. In this area there are at least two stacked parasequences arranged in a progradational stacking pattern. Each parasequence was deposited as a result of an episode of sea-level fall. The two episodes are separated by an interval of time of approximately $120,000 \mathrm{y}$.
The progradational parasequence stacking pattern depicted in Van Wagoner et al. (1990) (their fig. 10) shows coastal plain sandstones and mudstones "prograding" on top of each parasequence. This architecture is difficult to reconcile with the results of our studies. We have observed that lagoonal sediments do not "prograde" over the shoreline sandstones. These sediments are deposited mostly during sea-level rise. When sea level falls, the lagoon becomes emergent and sedimentation ceases (Figs. 4 and 13C). If the relative sea level rises during progradation of the shoreline, lagoonal sediments could conceivably "prograde" over shoreline sandstones. However, this would require a delicate balance between areal expansion of the lagoon and sediment supply for progradation of the shoreline. If the lagoon expands too much, it will trap sediments and shoreline progradation could stop.

Another confusing point is how to define the onshore equivalent of the marine flooding surface (MSF) that separates parasequences. Observation of Fig. 13B shows that, offshore, the MSF coincides with the ravinement surface. Onshore, however, it is difficult to establish the MFS correlative surface, because there is an increase in water depth at the ravinement surface as well as at the surface that separates the lagoonal sediments from the underlying shoreline sandstones deposited during the previous progradational episode (Fig. 13B). This happens because during transgression, once the barrier island forms, the retreating shoreline splits into two, one at the open ocean beach and the other at the mainland lagoon margin (Fig. 13B). As a result, the MFS splits onshore into two surfaces bounding the sedimentary prism deposited in the lagoon. In a sense, this lagoonal prism is a kind of "expanded section" correlative of the "condensed section" that may form further offshore associated with development of the parasequence boundary.

Van Wagoner et al. (1990), discussing parasequence depositional mechanisms, suggest that they form as a result of varying rates of sea-level change during a relative sea-level rise. However, drops in relative sea level of a few metres (5th order eustatic cycles of Van Wagoner et al., 1990), during an overall episode of relative sea-level 
rise, could produce parasequences without necessarily leading to sequence boundary development (Figs. 13C-13E). It should be noted that in our example, the Pleistocene parasequence is separated from the Holocene one by a sequence boundary, because sea level during the Late Pleistocene, has fallen more than $100 \mathrm{~m}$. A much smaller fall in relative sea level followed by a rise could produce the same architecture without necessarily generating a sequence boundary (Figs. 13C-13E).

The average time reported in the literature for the accumulation of sandstone shoreline parasequence sets is of the order of 1-10 m.y. Thus, in order for these parasequence sets to accumulate, it is necessary that sediment dispersal systems (i.e. wave-generated longshore currents) remain unchanged in these time scales. This would allow sediment to be continuously delivered to the sediment traps located along the coast. It is this persistence, modulated by changes in relative sea level, that probably allows the accumulation of the extensive sandstone shoreline parasequence sets in the geologic record. Why should coastal sediment dispersal patterns remain unchanged for such a long time? The study of the east-northeastern coast of Brazil provides a possible answer.

Patterns of sediment dispersal and accumulation along the coastal zone are controlled by the wave climate affecting this region, which in its turn is controlled by the atmospheric circulation affecting this sector of the planet. In the case of east-northeastern Brazil, winds capable of generating waves are associated with the South Atlantic high-pressure cell and the advance of the polar fronts. These patterns of atmospheric circulation tend to persist for long periods of time, being modified only when changes in the geography of the continental blocks occur as a result of the movement of the tectonic plates. Since the lateral displacement of the tectonic plates averages just a few centimetres a year, important changes in the geographical position of the continental blocks will not occur in time scales shorter than 1-10 m.y. Accumulation of sediments on beach-ridge plains located along the east-northeastern coast of Brazil has not been continuous during the Quaternary but was interrupted by the rise in sea level associated with the last episode of deglaciation. Progradation of the shoreline then resumed after $5.1 \mathrm{ka}$ as a result of a drop in relative sea level producing stacking of two parasequences. Because atmospheric circulation patterns on the South Atlantic will probably persist for a considerable period of time, it is probable that extensive sandstone shoreline parasequences will accumulate along the east-northeastern coast of Brazil if sediment supply remains adequate.

\section{Acknowledgements}

Financial support for this research was provided by the Conselho Nacional de Desenvolvimento Científico e Tecnológico (CNPq, Brazil) through various grants awarded to the authors during the last ten years.

Thanks are also extended to the convenors of the SEPM-IGCP-274 Quaternary Coastal Evolution Research Conference for inviting us to participate in this special volume. The final manuscript benefited from critical reviews by Fred L. Wehr and John R. Sutter.

\section{References}

Balsley, J.K., 1983. Cretaceous wave-dominated delta systems - Book Cliffs, East-Central Utah, Fieldguide. Oklahoma City Geological Society, 219 pp.

Bandeira, A.N., Jr., Petri, S. and Suguio, K., 1975. Projeto Rio Doce. Petroleo Brasileiro S.A., Internal Rep., 203 pp.

Barbosa, L.M., Bittencourt, A.C.S.P., Dominguez, J.M.L. and Martin, L., 1986a. The Quaternary coastal deposits of the State of Alagoas: influence of the relative sea-level changes. In: J. Rabassa (Editor), Quaternary of South America and Antarctica Peninsula, Vol. 4. Balkema, Rotterdam, pp. 269-290.

Barbosa, L.M., Bittencourt, A.C.S.P., Dominguez, J.M.L. and Martin, L., 1986b. Mapa Geológico do Quaternário Costeiro do Estado de Alagoas (jointly published with the Mapa Geológico do Estado de Alagoas, 1:250,000). Departamento Nacional da Produção Mineral. Série Mapas e Cartas de Síntese, 2, Seção Geologia No. 2, Recife.

Bigarella, J.J., 1972. Eolian environments-their characteristics, recognition and importance. In: J.K. Rigby and W.L. Hamblin (Editors), Recognition of Ancient Sedimentary Environments. SEPM, Spec. Publ., 16: pp. 12-14. 
Bittencourt, A.C.S.P., Dominguez, J.M.L., Martin, L. and Ferreira, Y.A., 1981. Dados preliminares sobre a evolução do delta do rio São Francisco (SE/AL) durante o Quaternário; influência das variações do nível do mar. Atas do IV Simpósio do Quaternário no Brasil, Soc. Bras. Geologia, pp. 49-68.

Bittencourt, A.C.S.P., Martin, L., Dominguez, J.M.L. and Ferreira, Y.A., 1983a. Mapa Geológico do Quaternário Costeiro do Estado de Sergipe (jointly published with the Mapa Geológico do Estado de Sergipe, 1:250,000). Dep. Nac. Produção Mineral, Brazil.

Bittencourt, A.C.S.P., Martin, L., Dominguez, J.M.L. and Ferreira, Y.A., 1983b. Evolução paleogeográfica quaternária da costa do Estado de Sergipe e da costa sul do Estado de Alagoas. Rev. Bras. Geocien., 13: 93-97.

Bittencourt, A.C.S.P., Dominguez, J.M.L. and Moita Filho, O., 1990. Variações Texturais Induzidas Pelo Vento nos Sedimentos da Face da Praia (Praia de Atalaia-Piauí): Implicaçōes Paleoclimáticas. Rev. Bras. Geocienc., 20: 201-207.

Clifton, H.E., 1981. Progradational sequences in Miocene shoreline deposits, southeastern Caliente Range, California. J. Sediment. Petrol., 51: 165-184.

Coleman, J.M. and Wright, L.C., 1975. Modern river deltas; variability of process and sand bodies. In: M.L. Broussard (Editor), Deltas, Models for Exploration. Houston Geol. Soc., Tx., pp. 99-150.

Curray, J.R., Emmel, F.J. and Crampton, P.J.S., 1967. Holocene history of a strandplain, lagoonal coast, Nayarit, Mexico. In: A.A. Castenares and F.B. Phelger (Editors), Lagunas Costeras, Un Simposio. Univ. Nac. Auton. Mex., pp. 63-100.

Davies, J.L., 1972. Geographical Variation in Coastal Development. Longman Group Ltd., New York, N.Y., 204 pp.

Dominguez, J.M.L., 1983. Evolução Quaternária da planície costeira do rio Jequitinhonha (BA): influência das variações do nível do mar e da deriva litorânea de sedimentos. M.S. Thesis, Univ. Fed. Bahia, 79 pp. (unpublished).

Dominguez, J.M.L., 1984. Sea-level history: a dominant control on modern coastal sedimentation styles. SEPM, 1st Midyear Mtng, San Jose, Calif., p. 26 (abstr.).

Dominguez, J.M.L., 1987. Quaternary sea-level changes and the depositional architecture of beach-ridge strandplains along the east coast of Brazil. Ph.D. Dissertation, Univ. of Miami, $288 \mathrm{pp}$.

Dominguez, J.M.L. and Wanless, H.R., 1991. Facies architecture of a falling sea-level strandplain, Doce river coast, Brazil. In: D.J.P. Swift and G.F. Oertel (Editors), Shelf Sandstone Bodies. Int. Assoc. Sedimentol., Spec. Publ., 14: 259-289.

Dominguez, J.M.L., Bittencourt, A.C.S.P. and Martin, L., 1981. Esquema evolutivo da sedimentação quaternária nas feições deltáicas dos rios São Francisco (SE/AL), Jequitinhonha (BA), Doce (ES) e Paraíba do Sul (RJ). Rev. Bras. Geocienc., 11: 227-237.
Dominguez, J.M.L., Bittencourt, A.C.S.P. and Martin, L., 1983. O papel da deriva litorânea de sedimentos arenosos na construção das planícies costeiras associadas as desembocaduras dos rios São Francisco (SE/AL), Jequitinhonda (BA), Doce (ES) e Paraíba do Sul (RJ). Rev. Bras. Geocienc., 13; 98-105.

Dominguez, J.M.L., Martin, L. and Bittencourt, A.C.S.P., 1987. Sea-level history and the Quaternary evolution of river mouth-associated beach-ridge plains along the eastsoutheast coast of Brazil: a summary. In: D. Nummedal, D.H. Pilkey and J.D. Howard (Editors), Sea-Level Fluctuation and Coastal Evolution. SEPM, Spec. Publ., 41: 115127.

Dominguez, J.M.L., Bittencourt, A.C.S.P., Leão, Z.M.A.N. and Azevedo, A.E.G., 1990. Geologia do Quaternário Costeiro do Estado de Pernambuco. Rev. Bras. Geocienc., 20: 208-215.

Farias, F.F., Bittencourt, A.C.S.P., Zanini, A., Jr. and Dominguez, J.M.L., 1985. Variaçōes temporais e espaciais na dinâmica de sedimentação da praia de Armação, Salvador (BA). Rev. Bras. Geocienc., 15: 48-54.

Fisher, W.L., 1969. Facies characterization of the Gulf coast basin systems, with Holocene analogues. Gulf Coast Assoc. Geol. Soc. Trans., 19: 239-261.

Galloway, W.E., 1975. Process framework for describing the morphologic and stratigraphic evolution of deltaic depositional systems. In: M.L. Broussard (Editor), Deltas, Models for Exploration. Houston Geol. Soc., Tx., pp. 87-98.

Goldsmith, V., 1978. Coastal Dunes. In: R.A. Davies, Jr. (Editor), Coastal Sedimentary Environments. Springer, New York, N.Y., pp. 171-236.

Hastenrath, S. and Lamb, P.J., 1977. Climatic Atlas of the Tropical Atlantic and Eastern Pacific Oceans. The University of Wisconsin Press (not sequentially numbered).

Hayes, M.O., 1979. Barrier island morphology as a function of tidal and wave regime. In: S.P. Leatherman (Editor), Barrier Islands from the Gulf of St. Lawrence to the Gulf of Mexico. Academic Press, New York, N.Y., pp. 1-27.

Hewardalt, A.P., 1981. A review of wave-dominated clastic shoreline deposits. Earth Sci. Rev., 17: 223-276.

Hogben, N. and Lumb, F.E., 1967. Ocean wave statistics. National Physical Lab., Ministry of Technology, London, $263 \mathrm{pp}$.

Inman, D.L., Ewing, G.C. and Corliss, J.B., 1966. Coastal sand dunes of Guerrero Negro, Baja California, Mexico. Geol. Soc. Am. Bull., 77: 787-802.

Martin, L. and Dominguez, J.M.L., 1992. Geological history of coastal lagoons-with particular reference to examples from the east coast of Brazil. In: B. Kjerfve (Editor), Coastal Lagoon Processes. Elsevier, Amsterdam (in press).

Martin, L., Flexor, J.-M., Vilas Boas, G.S., Bittencourt, A.C.S.P. and Guimarães, M.M.M., 1979. Courbe de variations du niveau relatif de la mer au cours des 7000 dernières années sur un secteur homogène du littoral bresilien (nord de Salvador, Bahia). In: K. Suguio, R.R. Fairchild, L. Martin and J.-M. Flexor (Editors), Proc. 1979 
Int. Symp. Coastal Evolution in the Quaternary, São Paulo, pp. 264-274.

Martin, L., Bittencourt, A.C.S.P., Vilas Boas, G.S. and Flexor, J.-M., 1980. Mapa Geológico do Quaternário Costeiro do Estado da Bahia, escala 1:250,000. Coordenação da Produção Mineral, Secretaria das Minas e Energia do Estado da Bahia, Brasil.

Martin, L., Suguio, K., Flexor, J.-M., Dominguez, J.M.L. and Azevedo, A.E.G., 1984a. Evoluçāo da planície costeira do rio Paraíba do Sul (RJ) durante o Quaternário: influência das flutuaçóes do nível do mar. Anais do XXXIII Congresso Brasileiro Geologia, pp. 84.97.

Martin, L., Flexor, J.-M., Bittencourt, A.C.S.P. and Dominguez, J.M.L., 1984b. Registro do bloqueio da circulaçāo atmosférica meridiana na geometria dos cordóes litorâneos da costa brasileira. Anais do XXXIII Congresso Brasileiro Geologia, pp. 133-144.

Martin, L., Flexor, J.M., Blitzkow, D. and Suguio, K., 1985a. Geoid change indications along the Brazilian coast during the last 7000 years. Proc. 5th Int. Coral Reef Congr., Tahiti, 3: 85-90.

Martin, L., Suguio, K., Flexor, J.-M., Tessler, M. and Eichler, B.B., 1985b. Roundness in Holocene sands of the Paraíba do Sul coastal plain, Rio de Janeiro, Brazil. J. Coastal Res., 1: 343-351.

McCubbin, D.G., 1982. Barrier island and strandplain facies. In: P.A. Scholle and D. Spearing (Editors), Sandstone Depositional Environments. Am. Assoc. Pet. Geol. Mem., 31: 247-280.

Nimer, E., 1989. Climatologia do Brasil. Instituto Brasileiro de Geografia e Estatistica, Rio de Janeiro, $421 \mathrm{pp}$.

Purvis, K., 1991. Stoss-side mud-drapes: deposits of interdune pond margins. Sedimentology, 38: 153-156.

Rice, D.D., 1980. Coastal and deltaic sedimentation of Upper
Cretaceous Eagle Sandstone-relation to shallow gas at cumulations, North-Central Montana. Am. Assoc. Pet Geol. Bull., 64: 316-338.

Ryer, T.A., 1977, Patterns of Cretaceous shallow marine sedimentation, Coalville and Rockport areas, Utah. Geol Soc. Am. Bull., 88: 177-188.

Shepard, F.P., 1950. Longshore bars and longshore troughs. Tech. Mem., 15, Beach Erosion Board. U.S. Army Corps of Engineers, pp. 121-156.

Suguio, K., Martin, L. and Flexor, J.M., 1979. Sea-level fluctuations during the past 6,000 years along the coast of the state of São Paulo, Brazil. In: N.A. Mörner (Editor), Earth Rheology, Isostasy and Eustasy. Proc. Symp. Stockholm, 1977, John Wiley, New York, N.Y., pp. 471-486.

Suguio, K., Martin, L. and Dominguez, J.M.L., 1981. Evolução do delta do Rio Doce (ES) durante o Quaternário: influência das variaçóes do nível do mar. Atas do IV Simpósio do Quaternário no Brasil, Sociedade Brasileira de Geologia, Rio de Janeiro, pp. 93-116.

Swift, D.J.P., 1975. Barrier island genesis: evidence from the Central Atlantic shelf, Eastern U.S.A. Sediment. Geol., 14: $1-43$.

U.S. Navy, 1978. Marine Climatic Atlas of the World, Vol. IV, South Atlantic Ocean. Washington, D.C., 325 pp.

Van Wagoner. J.C., Mitchum, R.M., Campion, K.M. and Rahmanian, V.D., 1990. Siliciclastic Sequence Stratigraphy in Well Logs, Cores and Outcrops: Concepts for High-Resolution Correlation of Time and Facies. Am Assoc. Pet. Geol., Meth. Explor., Ser., 7, 55 pp.

Wright, L.D. and Short, A.D., 1983. Morphodynamics of beaches and surf zones in Australia. In: P.D. Komar (Editor), CRC Handbook of Coastal Processes and Erosion. CRC Press Inc., Florida, pp. 35-64. 